\title{
34. MOLECULAR COMPOSITION OF SEDIMENTARY LIPIDS OFF THE PERU MARGIN, LEG $112^{1}$
}

\author{
P. Farrimond, ${ }^{2,3}$ J. G. Poynter, ${ }^{2}$ and G. Eglinton ${ }^{2}$
}

\begin{abstract}
This study describes the molecular composition of the solvent-extractable organic matter of sediment samples from the Peru upwelling area, collected from Hole 686B, Ocean Drilling Program (ODP) Leg 112. The postulated biological sources of individual lipids are discussed, and their concentrations calculated for a representative sediment sample. The solvent-soluble organic matter is dominated by lipids of marine origin, derived from the highly productive photic zone. Terrigenous lipids are minor components. Comparison of a Peruvian upwelling sample with a sediment from the Cap Blanc upwelling off northwest Africa reveals largely similar biological sources of organic matter in both areas, although terrigenous material is of greater importance in the latter region. The paleoenvironmental information contained within the molecular distributions is also discussed to form a background for accompanying studies (this volume) concerning downhole fluctuations in lipid abundance and molecular characteristics and the paleoclimatic information recorded therein.
\end{abstract}

\section{INTRODUCTION}

The basis of most molecular organic geochemical studies lies in the concept of biological marker compounds. A biological marker ("biomarker" or "chemical fossil") is an organic compound having a structure that can be linked to a specific biological source (Eglinton and Calvin, 1967; Philp, 1985). Many such compounds are characteristic of a type of organism, although others may be considerably more specific (Brassell and Eglinton, 1983). Equally, many organic compounds present in the geosphere are nearly ubiquitous, and such compounds cannot strictly be termed biological markers.

The molecular marker approach has been applied to an enormous range of sediments, ancient and modern, from a wide variety of environments. These studies have shown that organic matter deposited in different environments is characterized by different molecular signals, depending upon both the assemblage of organisms contributing organic material to the sediments and the environmental conditions (Didyk et al., 1978; Brassell, 1984; Meyers et al., 1984; ten Haven et al., 1985; Mello et al., 1988). However, the application of biomarkers to infer the type and abundance of contributing organisms depends upon good chemotaxonomic control, and although the molecular compositions of a large number of contemporary organisms have been investigated, there remain a great number yet to be so characterized. There is also the difficult question of possible molecular changes as groups of organisms have evolved; in other words, do the molecular compositions of present-day biota accurately reflect those of organisms contributing organic matter to past sediments? Furthermore, effects on the composition of organic matter during transit through the food web and sediment diagenesis must be understood and allowed for. Nevertheless, despite these difficulties, molecular organic geochemical study of organic matter preserved in sediments can provide valuable information regarding past biological assemblages, depositional conditions, and climate.

\footnotetext{
${ }^{1}$ Suess, E., von Huene, R., et al., 1990. Proc. ODP, Sci. Results, 112: College Station, TX (Ocean Drilling Program).

2 Organic Geochemistry Unit, University of Bristol, School of Chemistry, Cantock's Close, Bristol BS8 ITS, United Kingdom.

${ }^{3}$ Organic Geochemistry Unit, University of Newcastle upon Tyne, Department of Geology, Drummond Building, Newcastle upon Tyne NEl 7RU, United Kingdom.
}

The Peruvian upwelling is often recognized as the classic example of a coastal upwelling environment and, consequently, has received a great deal of scientific study. Upwelling of cool, nutrient-rich waters, driven by the combined action of southeasterly trade winds and the Earth's Coriolis forces, results in high surface productivity over a wide coastal band off Peru and Chile (Zuta et al., 1978; Smith, 1983). The consequent high supply of particulate organic matter (1 to 3 $\mathrm{gC} \cdot \mathrm{m}^{-2} \cdot \mathrm{d}^{-1}$ or higher; Ryther et al., 1971; Henrichs and Farrington, 1984; Suess et al., 1987) results in high oxygen demand in the water column. In turn, this supports an oxygen-minimum zone that impinges on the continental slope from approximately 75 to $800 \mathrm{~m}$ below the sea surface (Gagosian et al., 1980; Rosenberg et al., 1983; Henrichs and Farrington, 1984; Rowe and Howarth, 1985). Consequently, the sediments deposited in this region of the continental slope are rich in organic matter (Demaison and Moore, 1980; Gagosian et al., 1983a; Suess et al., 1987) and ideal for organic geochemical study. Indeed, their importance as modern analogues of petroleum source rocks (e.g., Monterey Formation of California; Donegan and Schrader, 1981; Williams, 1984) and the excellent preservation of climatic records in their constituent organic matter has resulted in extensive organic geochemical study of the Peru upwelling area. These studies have addressed both water-column particulate matter (Gagosian et al., 1983a, 1983b; Repeta and Gagosian, 1983; Wakeham et al., 1983, 1984) and the underlying sediments (Smith et al., 1983a, 1983b; Poutanen and Morris, 1983; Reimers and Suess, 1983; Volkman et al., 1983, 1987; Henrichs and Farrington, 1984; Henrichs et al., 1984; Cooper et al., 1986; Repeta and Gagosian, 1987; Rowe and Howarth, 1985) and have been directed to a wide variety of molecular components (sterols, fatty acids, ketones, hydrocarbons, carotenoids, amino acids, and humic acids). Most of these scientists discussed the biological marker distributions of surface sediments in the Peru upwelling area, the probable biological sources of the organic matter, and its early diagenetic modification.

Our purpose here is to identify the molecular components of sediment samples recovered during Leg 112 (Site 686) and thus infer the biological sources of the sedimentary organic matter. This discussion serves as an introduction to a companion paper (this volume), where the biological marker approach is used to infer changes in climate and environmen- 


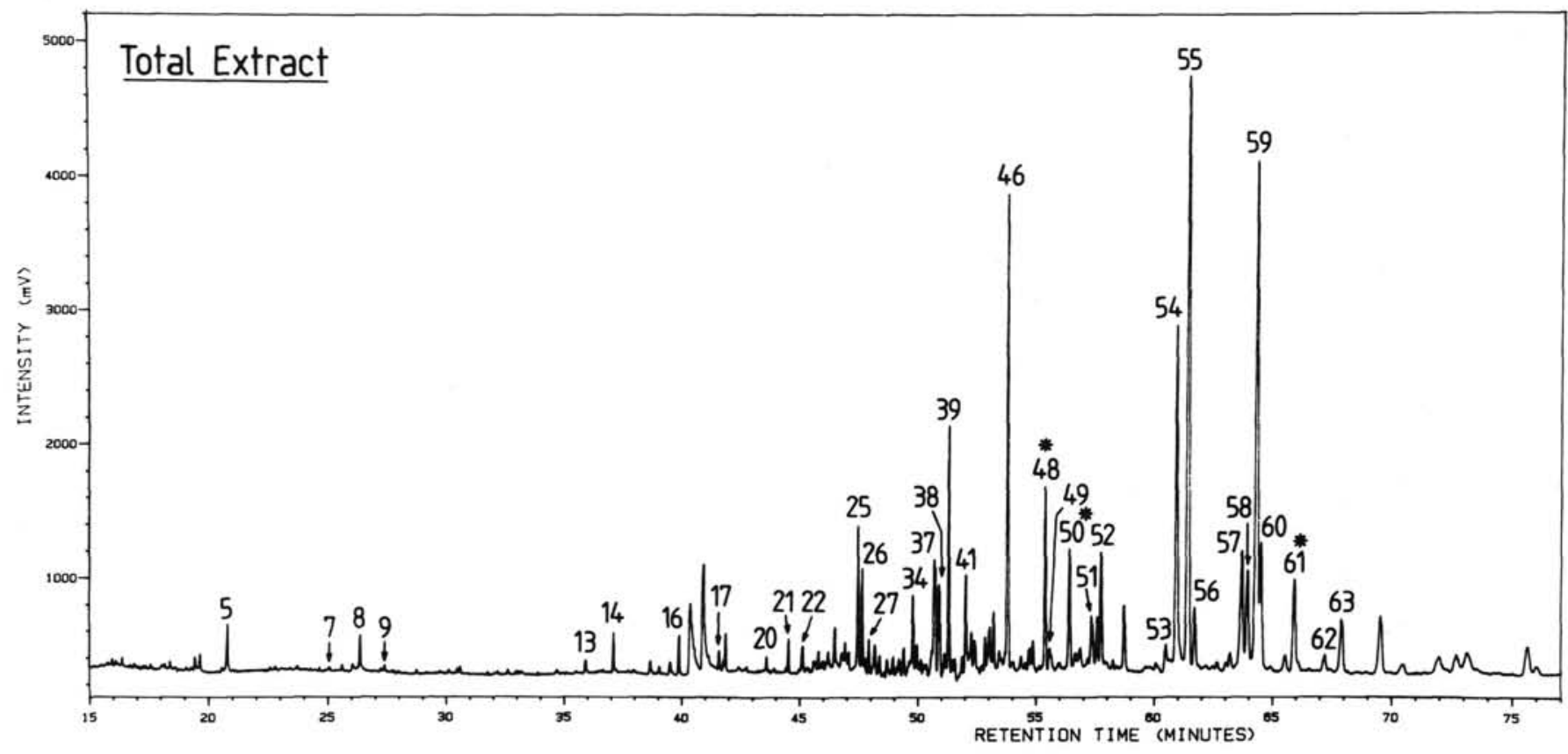

Figure 1. A gas chromatogram of the total lipid extract of Sample 112-686B-2H-4, 40-43 cm (see "Experimental Methods" section [this chapter] for analytical details). Compound assignments are listed in Table 1.

tal conditions over the last several hundred thousand years ("molecular stratigraphy").

\section{EXPERIMENTAL METHODS}

Frozen sediment samples were thawed and homogenized before removing an aliquot (about $0.3 \mathrm{~g}$ dry weight) for lipid extraction. The samples were extracted with ultrasonification (sonic bath) in six 15-min steps $\left(2 \times 4 \mathrm{~cm}^{3}\right.$ methanol; $4 \mathrm{~cm}^{3}$ methanol/dichloromethane $1: 1 ; 3 \times 4 \mathrm{~cm}^{3}$ dichloromethane). After each step, the sample was centrifuged and its clear extract decanted; all extracts were combined. A known quantity of internal standard $\left(C_{36}\right.$ n-alkane; $C_{40}$ n-alkane; cholesteryl hexanoate) was added to each sample after the second methanol extraction step to allow later quantitation of lipid abundances. After extraction, the sediments were oven-dried and weighed. Organic extracts were washed with aqueous $\mathrm{KCl}$ to separate salts and water, and the organic layer was removed. The remaining aqueous layer was extracted once more with $5 \mathrm{~cm}^{3}$ dichloromethane. These organic extracts were combined and excess solvent was removed by rotary evaporation before being stored dry in vials at $4^{\circ} \mathrm{C}$.

Analysis by gas chromatography was routinely applied to the total lipid extracts without prior fractionation. Samples were analyzed within several days of extraction to minimize loss of labile lipids and were derivatized with bis-(trimethylsilyl) trifluoroacetamide (BSTFA) before analysis. Gas chromatography was performed using a Carlo Erba Mega Series 5300 machine fitted with an on-column injector and an OV-1 fused silica capillary column $(50-\mathrm{m} \times 0.32-\mathrm{mm}$ internal diameter). An OV-1 precolumn $(5-\mathrm{m} \times 0.32-\mathrm{mm}$ internal diameter) was connected to the main column using a Hewlett-Packard zero dead-volume capillary column connector; this served to trap out the polar compounds, thus protecting the main column. Upon noticeable loss of resolution, the pre-column was trimmed by $0.5 \mathrm{~m}$; in this way, the main column did not need regular trimming, despite the highly polar nature of our samples. Analyses were performed using hydrogen carrier gas, with an oven temperature program of $40^{\circ}$ to $150^{\circ} \mathrm{C}$ at $10^{\circ} \mathrm{C} / \mathrm{min}$ and $150^{\circ}$ to $310^{\circ} \mathrm{C}$ at $4^{\circ} \mathrm{C} / \mathrm{min}$. Data were acquired using an on-line Minichrom data system.

In addition, an aliquot of the total extract of one sample (112$686 \mathrm{~B}-2 \mathrm{H}-4,40-43 \mathrm{~cm}$ ) was fractionated by column chromatography to facilitate compound identification (based on the procedure of Volkman et al., 1983). The column was packed with activated silica (3-cm bed depth in a $5-\mathrm{mm}$ internal diameter Pasteur pipette) in hexane. Four fractions were collected upon elution with (1) hexane (6 $\left.\mathrm{cm}^{3}\right),(2)$ hexane/ethyl acetate $\left(95: 5 ; 6 \mathrm{~cm}^{3}\right),(3)$ hexane/ethyl acetate
(80:20;6 $\left.\mathrm{cm}^{3}\right)$ and (4) methanol $\left(4 \mathrm{~cm}^{3}\right)$. These fractions correspond to (1) "hydrocarbons," (2) "sterols and alkenones," (3) "n-alkanols and alkan-1,15-diols," and (4) "residuals."

Subsequent analyses by gas chromatography-mass spectrometry (GC-MS) of the fractions and total extract were performed using a Carlo Erba Mega Series 5160 gas chromatograph linked to a Finnigan 4000 quadrupole mass spectrometer. The gas chromatograph was fitted with an on-column injector and an OV-1 (cross-linked methylsilicone) fused silica capillary column $(50-\mathrm{m} \times 0.32-\mathrm{mm}$ internal diameter) was temperature programmed from $50^{\circ}$ to $150^{\circ} \mathrm{C}$ at $10^{\circ} \mathrm{C} / \mathrm{min}$ and $150^{\circ}$ to $310^{\circ} \mathrm{C}$ at $4^{\circ} \mathrm{C} / \mathrm{min}$, using helium as carrier gas. The mass spectrometer was operated in $\mathrm{El}$ mode (ionizing energy of $35 \mathrm{eV}$; ion source temperature of $250^{\circ} \mathrm{C}$ ) with a scan time $(\mathrm{m} / \mathrm{z} 50-600)$ of $1 \mathrm{~s}$. An INCOS 2300 system was used for data acquisition and processing.

Compounds were identified by a combination of their mass spectra (compared with authentic standards and literature sources), mass fragmentographic responses, and relative retention times.

\section{MOLECULAR COMPOSITION AND SIGNIFICANCE}

Site 686 is located in the West Pisco Basin at a water depth of $447 \mathrm{~m}$. During a molecular study of the solvent-soluble organic matter in a suite of sediments from Hole 686B, we noted that the same organic compounds occurred throughout, although their relative concentrations varied (see Farrimond et al., this volume). Consequently, here we illustrate our discussion with detailed results from a single sediment sample (112-686B-2H-4, 40-43 cm), although the molecular composition of this sample is characteristic of the entire sequence. The sediment sample was taken from $13.4 \mathrm{~m}$ below seafloor (bsf) and is of Quaternary age. This sample is described as a dark olive diatomaceous mud. A gas chromatogram of the total extract of this sediment is shown in Figure 1.

\section{Hydrocarbons}

Hydrocarbons make up only a minor proportion of the solvent-soluble organic matter. A series of long-chain nalkanes occurs ( $n-C_{16}$ to $n-C_{35} ;$ Fig.2), maximizing at $n-C_{29}$ to $\mathrm{n}-\mathrm{C}_{31}$ (about 360 and $660 \mathrm{ng} / \mathrm{g}$ dry sediment in Sample 112$686 \mathrm{~B}-2 \mathrm{H}-4,40-43 \mathrm{~cm}$ ); odd carbon-number homologues dominate even carbon numbers in the long-chain $\left(>C_{25}\right)$ region. 


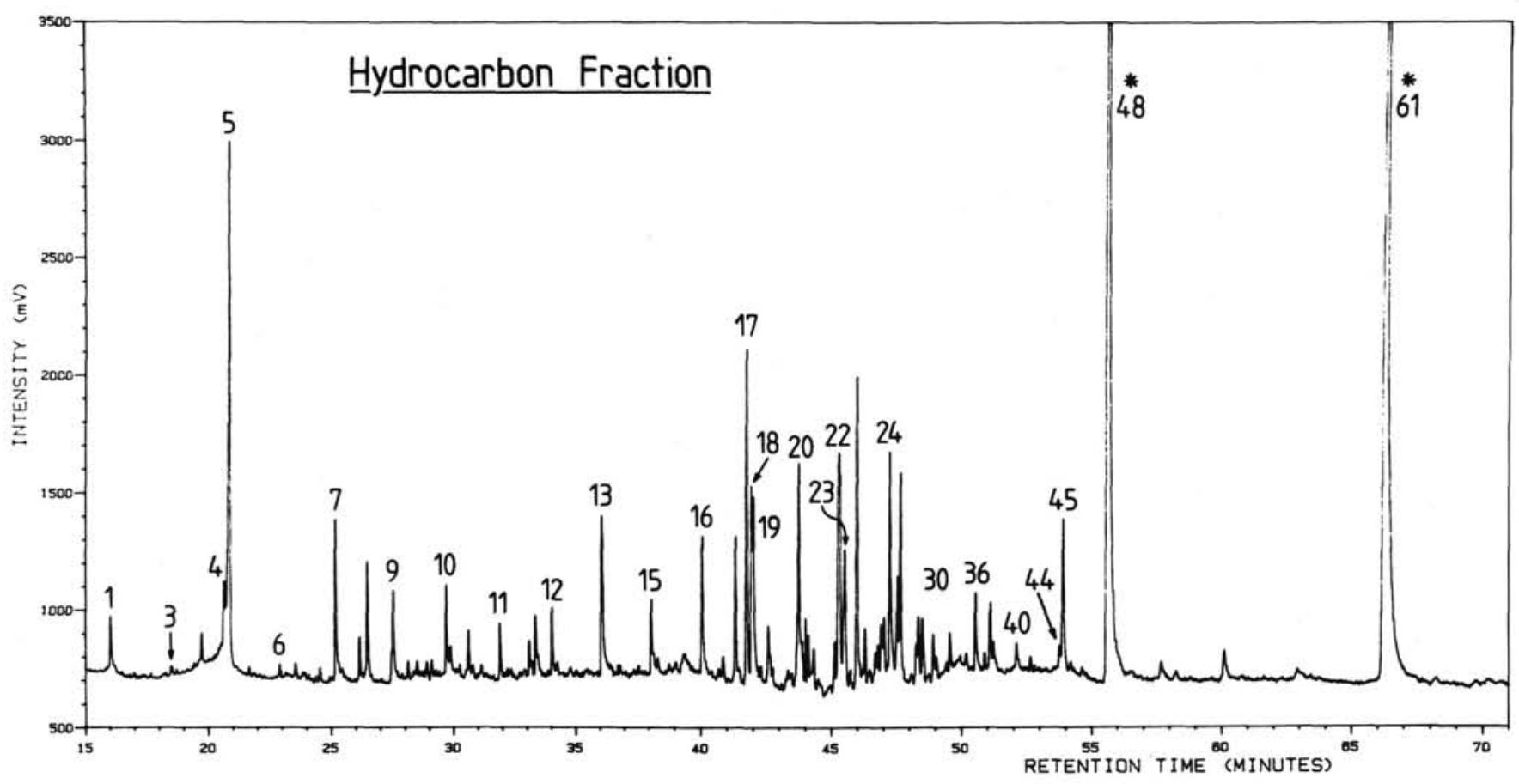

Figure 2. A gas chromatogram of the hydrocarbon fraction afforded after column chromatography of Sample 112-686B-2H-4, 40-43 cm (see "Experimental Methods" section [this chapter] for fractionation details; GC conditions as for Fig.1). Compound assignments are given in Table 1.

Such distributions of long-chain n-alkanes have been observed previously (e.g., Volkman et al., 1983) and are assumed to reflect contribution from terrestrial higher plants (Eglinton et al., 1962; Eglinton and Hamilton, 1967; Kolattukudy, 1976). These lipids may be introduced into the marine environment by fluvial transport or by an eolian mechanism. However, results from previous organic geochemical studies in this area suggest that although longchain n-alkanes of the correct carbon-number distribution occur in eolian dusts (Schneider et al., 1983), the flux transported via this method is insufficient to explain the concentrations in the sediments. On the basis of this observation and the relative importance of oxidized terrigenous lipids in at least some Peru margin sediments, Volkman et al. (1987) favored a fluvial influx for the bulk of the terrestrial organic matter in the area.

Phytane has been tentatively identified (peak 5; Fig. 2; assigned on the basis of retention time only because of a poor mass spectrum) in the sediments. This compound may arise from phytol (Didyk et al., 1978) or directly from a bacterial source (methanogens and/or halobacteria; Han and Calvin, 1969; Risatti et al., 1984). Both pristane and phytane have been previously reported in a surface sediment in the Peru upwelling area (Smith et al., 1983a). Lycopane (peak 45; Fig. 2) $\mathrm{a} \mathrm{C}_{40}$ acyclic isoprenoid alkane, occurs in low abundance in these sediments (about $400 \mathrm{ng} / \mathrm{g}$ in Sample 112-686B-2H-4, $40-43 \mathrm{~cm}$ ). Unfortunately, in the total extract (Fig. 1), lycopane co-elutes with $C_{30}$ alkane-1,15-diol, precluding accurate quantification of this compound. Positive identification of lycopane was only possible by GC-MS analysis of the hydrocarbon fraction (Fig. 2). The biological source of lycopane remains uncertain, although a bacterial origin, probably methanogenic bacteria, was proposed (Brassell et al., 1981). Farrington et al. (1988) identified lycopane in surface and nearsurface sediments in the Peru upwelling area and observed a relationship between total organic carbon content and lyco- pane concentration, consistent with a link between bacterial biomass and available substrate (high organic supply and/or low oxygen concentration).

Ster-4-enes and ster-5-enes, principally the $\mathrm{C}_{27}$ (peaks 17 and 18) and $C_{29}$ (peaks 22 and 23) compounds, occur as minor components in the sediments (about 300 to $600 \mathrm{ng} / \mathrm{g}$ sediment in $112-686 \mathrm{~B}-2 \mathrm{H}-4,40-43 \mathrm{~cm}$ ). These compounds presumably derive from sterol and/or steroidal ketone precursors (Mackenzie et al., 1982), either by transformation in the water column or through early diagenetic modification.

\section{Steroidal Alcohols}

4-Desmethylsterols are abundant constituents in the total extracts of the sediments (Fig. 1). Cholest-5-en-3 $\beta$-ol (cholesterol; peak 25) typically dominates the sterols $(4620 \mathrm{ng} / \mathrm{g}$ in $112-686 \mathrm{~B}-2 \mathrm{H}-4,40-43 \mathrm{~cm}) ; 5 \alpha(\mathrm{H})$-cholestan-3 $\beta$-ol (cholestanol; peak 26) occurs in significant abundance $(2770 \mathrm{ng} / \mathrm{g}$; Figs. 1 and 3 ) and is presumably derived, at least in part, through diagenetic reduction of cholesterol (via ketone intermediates; Gaskell and Eglinton, 1975; Nishimura and Koyama, 1977; Mackenzie et al., 1982). These compounds have been previously reported as major compounds in Peru sediments (Smith et al., 1983b; Volkman et al., 1987) and probably derive exclusively from marine sources, particularly from fecal pellets, molts and carcasses of zooplankton, and anchoveta fecal pellets (Gagosian et al., 1983b; Volkman et al., 1987).

Several 24-methylsterols were identified, including 24methylcholesta-5-22-dien-3 $\beta$-ol (peak 28) and 24-methylcholesta-5,24(28)-dien-3 $\beta$-ol (peak 31; Fig.3), both of which have been recognized previously as significant components in Peru upwelling sediments (Smith et al., 1983b; Volkman et al., 1987) and have been ascribed to a diatom source (Volkman, 1986). Other positively identitied 24-methylsterols are 24methylcholest-5-en-3 $\beta$-ol (peak 32), a common constituent of phytoplankton (Volkman, 1986) and vascular plants (Volkman 


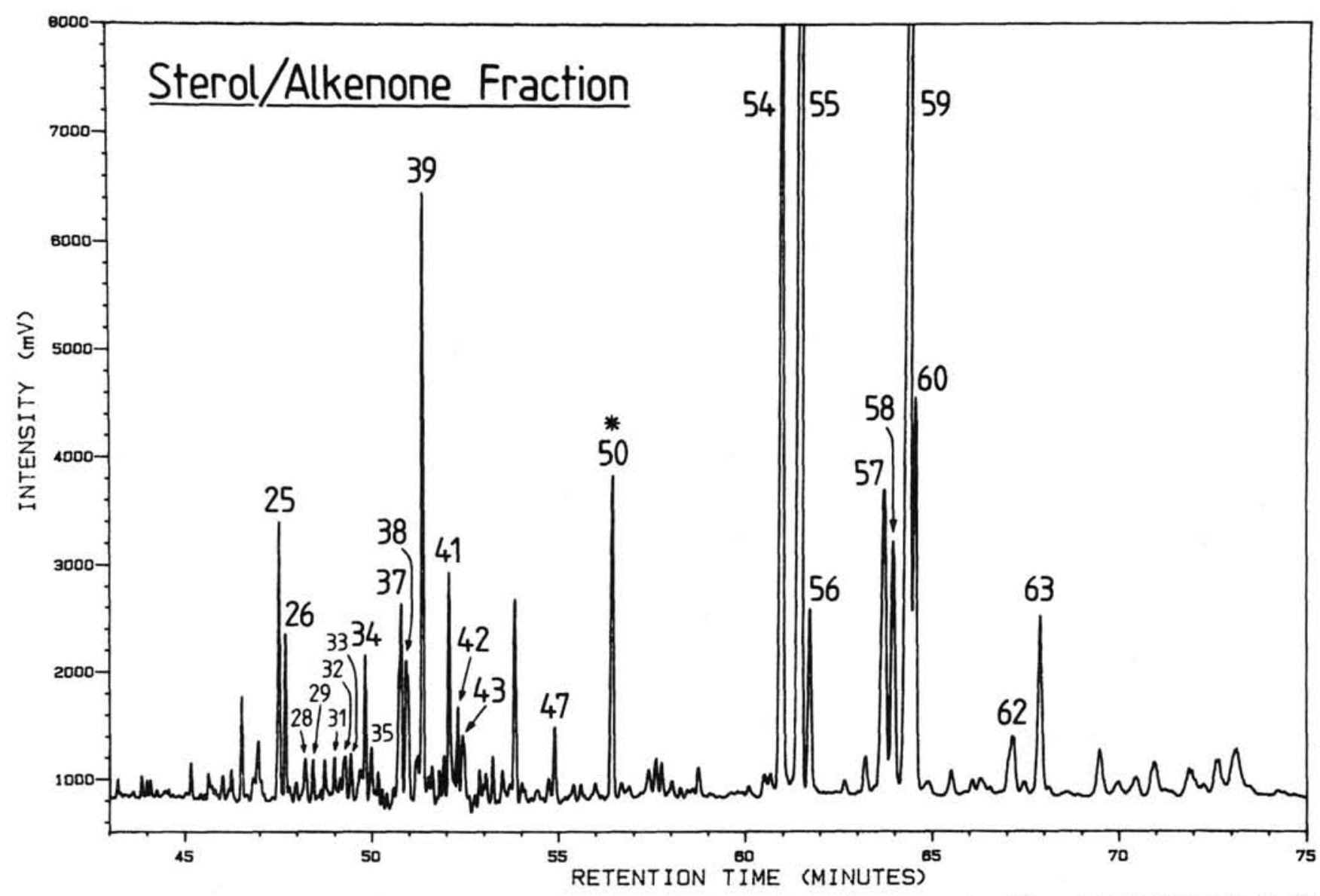

Figure 3. A gas chromatogram of the "sterol + alkenone" fraction afforded by column chromatography of Sample 112-686B-2H-4, 40-43 $\mathrm{cm}$ (see "Experimental Methods" section [this chapter] for details of fractionation and GC analysis). Compound assignments are given in Table 1.

et al., 1987), 24-methylcholestan-3 $\beta$-ol (peak 33) and 24methylcholest-22-en-3 $\beta$-ol (peak 29).

24-Ethylcholest-5-en-3 $\beta$-ol (peak 37; Fig. 3; co-elutes with 23,24-dimethylcholestan-3 $\beta$-ol) is a prominent component (7240 ng/g in 112-686B-2H-4, 40-43 cm), as observed in Peru sediments in previous studies (Smith et al., 1983b; Cooper et al., 1986; Volkman et al., 1987). The source of this compound is difficuit to assess, as it occurs in terrestrial higher plants (Volkman, 1986) as well as in a variety of algae (Volkman et al., 1981; Volkman, 1986). Smith et al. (1983b) argued for a predominantly marine origin in the Peru area on the basis of an absence of other land plant lipids, while Volkman et al. (1987) suggested that 24 -ethylcholest- 5 -en- $3 \beta$-ol is derived from both marine and terrestrial sources, with preferential survival of the terrigenous component with depth.

Other $\mathrm{C}_{29}$ sterols positively identified in this study are 24 -ethylcholestan-3 $\beta$-ol (peak 38), 24 -ethylcholest-22E-en-3 $\beta$ ol (peak 35) and 23,24-dimethylcholest-22E-en-3 $\beta$-ol (peak 34; Fig. 3). More detailed future GC-MS analyses of the sterol fraction will undoubtedly reveal a much greater complexity of sterols (see Smith et al., 1983b).

4-Methylsterols are significant components of the sedimentary organic matter on the Peru margin. Indeed, in the sample discussed here (112-686B-2H-4, 40-43 cm), $4 \alpha, 23,24$-trimethylcholest-22E-en-3 $\beta$-ol (dinosterol; peak 39; Fig. 3 ) is the most abundant steroidal compound ( 8230 $\mathrm{ng} / \mathrm{g}$ dry sediment). Many scientists think that dinosterol is characteristic of dinoflagellate influx to sediments (Boon et al., 1979; de Leeuw et al., 1983), and has been previously noted as an important constituent in the Peru area (Smith et al., 1983b; Cooper et al., 1986). Certainly, dinoflagellates are common in this environment (Dugdale et al., 1977; Gagosian et al., 1983a). Other identified 4-methylsterols are 4 $\alpha, 23,24$ trimethylcholest-8(14)-en-3 $\beta$-ol (peak 41), $4 \alpha, 23(\mathrm{~S}), 24(\mathrm{R})$ trimethylcholestan-3 $\beta$-ol (peak 42 ) and $4 \alpha, 23(\mathrm{R}), 24(\mathrm{R})$-trimethylcholestan-3 $\beta$-ol (peak 43, Fig. 3); these compounds may also be of dinoflagellate origin (e.g., Harvey et al., 1987). Peaks 42 and 43 were assigned on the basis of relative retention times (Smith, 1984).

\section{Long-Chain Alkenones and Alkanoates}

Long-chain $\left(\mathrm{C}_{3}-\mathrm{C}_{39}\right)$ di- and tri-unsaturated alkenones (Rechka and Maxwell, 1988) are the most abundant molecular constituents of the total organic extracts in this study (Fig. 1). A related ester, $\mathrm{C}_{37}$ methyl alkadienoate (37:2Me ester; peak 56; Figs. 1 and 3), also occurs. The major alkenone, $\mathrm{C}_{37}$ diunsaturated methyl ketone $(37: 2 \mathrm{Me}$; peak 55$)$ makes up almost $35 \mu \mathrm{g} / \mathrm{g}$ dry sediment in Sample 112-686B-2H-4, 40-43 $\mathrm{cm}$ (Table 1). These alkenones have been previously noted as significant organic components, both in the Peru sediments (Volkman et al., 1983; Smith et al., 1983a; Farrington et al., 1988) and in the water column (Wakeham et al., 1984). They are believed to be characteristic of Prymnesiophyte algae, particularly Emiliania huxleyi (Volkman et al., 1980a, 1980b; Marlowe et al., 1984a, 1984b), which is well known in the Peru upwelling, although its distribution is patchy (Ryther et al., 1971). In recent years, it has become apparent that the degree of unsaturation in this suite of alkenones reflects the water temperature in which the source alga grew (Eglinton et al., 1983; Marlowe, 1984; Brassell et al., 1986a, 1986b; Prahl and 
Table 1. Compound identities and concentrations in the total organic extract of Sample 112-686B-2H-4, $40-43 \mathrm{~cm}$.

\begin{tabular}{|c|c|c|}
\hline Peak & Compound & $\begin{array}{l}\text { Concentration } \\
\text { (ng/g) }\end{array}$ \\
\hline 1 & $\mathrm{n}-\mathrm{C}_{16}$ alkane & - \\
\hline 2 & $\mathrm{n}-\mathrm{C}_{17}$ alkane & 140 \\
\hline 3 & Pristane & 200 \\
\hline 4 & $\mathrm{n}-\mathrm{C}_{18}$ alkane & 150 \\
\hline 5 & Phytane & 1,710 \\
\hline 6 & $\mathrm{n}-\mathrm{C}_{19}$ alkane & 130 \\
\hline 7 & $\mathrm{n}-\mathrm{C}_{20}$ alkane & 150 \\
\hline 8 & $\mathrm{n}-\mathrm{C}_{17}$ alkanol & 1,350 \\
\hline 9 & $\mathrm{n}-\mathrm{C}_{21}$ alkane & 270 \\
\hline 10 & $\mathrm{n}-\mathrm{C}_{22}^{21}$ alkane & - \\
\hline 11 & $\mathrm{n}-\mathrm{C}_{23}$ alkane & 85 \\
\hline 12 & $\mathrm{n}-\mathrm{C}_{24}$ alkane & 85 \\
\hline 13 & $\mathrm{n}-\mathrm{C}_{25}$ alkane (+ unknown) & about $100(+410)$ \\
\hline 14 & $\mathrm{n}-\mathrm{C}_{22}$ alkanol & 1,130 \\
\hline 15 & $\mathrm{n}-\mathrm{C}_{26}$ alkane & 89 \\
\hline 16 & $\mathrm{n}-\mathrm{C}_{27}$ alkane (+ unknown) & about $200(+1,070)$ \\
\hline 17 & Cholest-4-ene & 570 \\
\hline 18 & Cholest-5-ene & 300 \\
\hline 9 & $\mathrm{n}-\mathrm{C}_{28}$ alkane & - \\
\hline 20 & $\mathrm{n}-\mathrm{C}_{29}^{20}$ alkane & 360 \\
\hline 21 & $\mathrm{n}-\mathrm{C}_{26}$ alkanol & 940 \\
\hline 22 & 24-ethylcholest-4-ene (+ unknown) & 1,100 \\
\hline 23 & 24-ethylcholest-5-ene & - \\
\hline 24 & $\mathrm{n}-\mathrm{C}_{31}$ alkane & 660 \\
\hline 25 & Cholest-5-en-3 $\beta$-ol (cholesterol) & 4,620 \\
\hline 26 & Cholestan-3 $\beta$-ol (cholestanol) & 2,770 \\
\hline 27 & $\mathrm{n}-\mathrm{C}_{28}$ alkanol & 1,070 \\
\hline 28 & 24 -methylcholesta- 5,22 -dien- $3 \beta$-ol & 1,180 \\
\hline 29 & $\begin{array}{l}24 \text {-methylcholest-22-en-3 } \beta \text {-ol }+ \\
\text { cholest-7-en-3 } \beta \text {-ol }\end{array}$ & 700 \\
\hline 30 & $\mathrm{n}-\mathrm{C}_{32}$ alkane & - \\
\hline 31 & 24 -methylcholesta- $5,24(28)$-dien- $3 \beta$-ol & 610 \\
\hline 32 & 24 -methylcholest- 5 -en- $3 \beta$-ol & 650 \\
\hline 33 & 24-methylcholestan-3 $\beta$-ol & 1,090 \\
\hline 34 & 23,24 -dimethylcholest- 22 -en-3 $\beta$-ol & 2,330 \\
\hline 35 & 24-ethylcholest-22-en-3 $\beta$-ol & 750 \\
\hline 36 & $\mathrm{n}-\mathrm{C}_{33}$ alkane & 370 \\
\hline 37 & $\begin{array}{l}\text { 23,24-dimethylcholestan-3 } \beta \text {-ol }+ \\
\text { 24-ethylcholest-5-en-3 } \beta \text {-ol }\end{array}$ & 7,240 \\
\hline 38 & 24-ethylcholestan-3 $\beta$-ol & 4,970 \\
\hline 39 & $\begin{array}{l}4 \alpha, 23,24 \text {-trimethylcholest-22-en- } 3 \beta \text {-ol } \\
\text { (dinosterol) }\end{array}$ & 8,230 \\
\hline 40 & $\mathrm{n}-\mathrm{C}_{34}$ alkane & - \\
\hline 41 & $4 \alpha, 23,24$-trimethylcholest- $8(14)$-en- $3 \beta$-ol & 3,360 \\
\hline 42 & $4 \alpha, 23(\mathrm{~S}), 24(\mathrm{R})$-trimethylcholestan-3$\beta$-ol & 1,080 \\
\hline 43 & $4 \alpha, 23(\mathrm{R}), 24(\mathrm{R})$-trimethylcholestan- $3 \beta$-ol & 1,300 \\
\hline 44 & $\mathrm{n}-\mathrm{C}_{35}$ alkane & - \\
\hline 45 & Lycopane & - \\
\hline 46 & $\mathrm{C}_{30}$ alkane-1,15-diol + alkan-15-one-1-ol & 17,500 \\
\hline 47 & $\mathrm{C}_{31}$ hopanol? & 1,320 \\
\hline 48 & $\mathrm{n}-\mathrm{C}_{36}$ alkane (Internal standard) & - \\
\hline 49 & $\mathrm{C}_{31}$ alkane-1,15-diol + alkan-15-one-1-ol & 1,350 \\
\hline 50 & Cholesteryl hexanoate (Internal standard) & - \\
\hline 51 & Hopanol? & 2,900 \\
\hline 52 & $\mathrm{C}_{32}$ alkane-1,15-diol + alkan-15-one-1-ol & 5,230 \\
\hline 53 & $\mathrm{C}_{32}$ hopanol & 1,230 \\
\hline 54 & $37: 3 \mathrm{Me}$ alkenone & 17,700 \\
\hline 55 & $37: 2 \mathrm{Me}$ alkenone & 34,700 \\
\hline 56 & $37: 2 \mathrm{Me}$ ester & 3,200 \\
\hline 57 & 38:3Et alkenone & 7,960 \\
\hline 58 & $38: 3 \mathrm{Me}$ alkenone & 6,290 \\
\hline 59 & $38: 2 \mathrm{Et}$ alkenone & 32,100 \\
\hline 60 & $38: 2 \mathrm{Me}$ alkenone & 7,550 \\
\hline 61 & $\mathrm{n}-\mathrm{C}_{40}$ alkane (internal standard) & - \\
\hline 62 & $39: 3 \mathrm{Et}$ alkenone & 1,210 \\
\hline 63 & $39: 2$ Et alkenone & 4,120 \\
\hline
\end{tabular}

Note: Peak assignments refer to the gas chromatograms shown in Figures 1 through 4 .
Wakeham, 1987). The application of this temperature dependence to reconstruct past sea-surface temperature histories in the Peru upwelling has been addressed by Farrington et al. (1988) and Farrimond et al. (this volume).

\section{Alkane-1,15-diols and Alkan-15-one-1-ols}

Co-eluting $\mathrm{C}_{30}$ alkane-1,15-diol and alkan-15-one-1-ol (peak 46; Fig. 1) are major components (together being 17.5 $\mu \mathrm{g} / \mathrm{g}$ dry sediment in Sample 112-686B-2H-4, $40-43 \mathrm{~cm}$ ). The $\mathrm{C}_{32}$ compounds are also abundant (peak 52), and their $\mathrm{C}_{31}$ equivalents were recognized by GC-MS (peak 49). A similar distribution of these compounds, with the $\mathrm{C}_{30}$ components dominating, was reported previously in Peru upwelling sediments by Volkman et al. (1987), although Smith et al. (1983a) failed to find these components in this area. The biological origin of these compounds remains unclear, as they have been found in a variety of sedimentary environments, including the Black Sea (de Leeuw et al., 1981), the hypersaline Tyro Basin in the eastern Mediterranean (ten Haven et al., 1987), and in a coastal area at the mouth of the St. Lawrence estuary (Nichols and Johns, 1986). Recently, cyanobacteria were proposed as a source for alkanediols (Morris and Brassell, 1988).

\section{n-Alkanols}

Low quantities of n-alkanols (up to $1100 \mathrm{ng} / \mathrm{g}$ dry sediment in Sample 112-686B-2H-4, 40-43 cm; Table 1) were detected in the samples (Fig. 1). Most significant of these are the $\mathrm{C}_{22}$ to $\mathrm{C}_{28}$ compounds, which occur with high even-over-odd carbon number predominance. These compounds have been detected previously in Peru sediments (Volkman et al., 1987; although reported absent by Smith et al., 1983a), and many think they derive from higher plants (Kolattukudy, 1976; Cranwell and Volkman, 1981).

\section{Other Compounds}

Several hopanols $\left(\mathrm{C}_{31}\right.$ and $\mathrm{C}_{32}$ compounds) were identified in the samples used here (Fig. 1), and by previous scientists (e.g., Volkman et al., 1987). These compounds were ascribed to bacteria (Ourisson et al., 1979).

Fatty acids were not studied quantitatively in this study. Our sample work-up procedure did not include an acidification step; thus, loss of fatty acid salts was expected. Nevertheless, traces of fatty acid were identified by GC-MS analysis of the total extracts. Previous studies (Smith et al., 1983a; Wakeham et al., 1984; Farrington et al., 1988) showed that fatty acids are a quantitatively important suite of compounds in both the sediments and water column in the Peru upwelling area.

\section{Peru Upwelling vs. Cap Blanc Upwelling}

The molecular characteristics of solvent extracts of sediments from the Peru upwelling (Site 686; this study) are strikingly similar to those of sediments from the upwelling region off northwest Africa (Site 658; Poynter et al., in press). In both areas, the lipid distributions are dominated by longchain $\left(\mathrm{C}_{3}-\mathrm{C}_{39}\right)$ alkenones and the $\mathrm{C}_{30}$ alkane-1,15-diol (Fig. 4). Dinosterol and cholesterol are the major sterols in both regions, and long-chain n-alkanes and n-alkanols occur (Fig. 4), although the latter are far greater in the Cap Blanc upwelling off northwest Africa than in the Peru upwelling. Apparently, comparable biological influxes of sedimentary organic matter characterize both upwelling areas, with marine primary productivity dominating a smaller (much smaller in the case of Peru) contribution from terrestrial higher plants. However, the inferred biological sources of the major marinederived lipids (alkenones from Prymnesiophyte algae, alkanediols from cyanobacteria, dinosterol from dinoflagellates, etc.) 

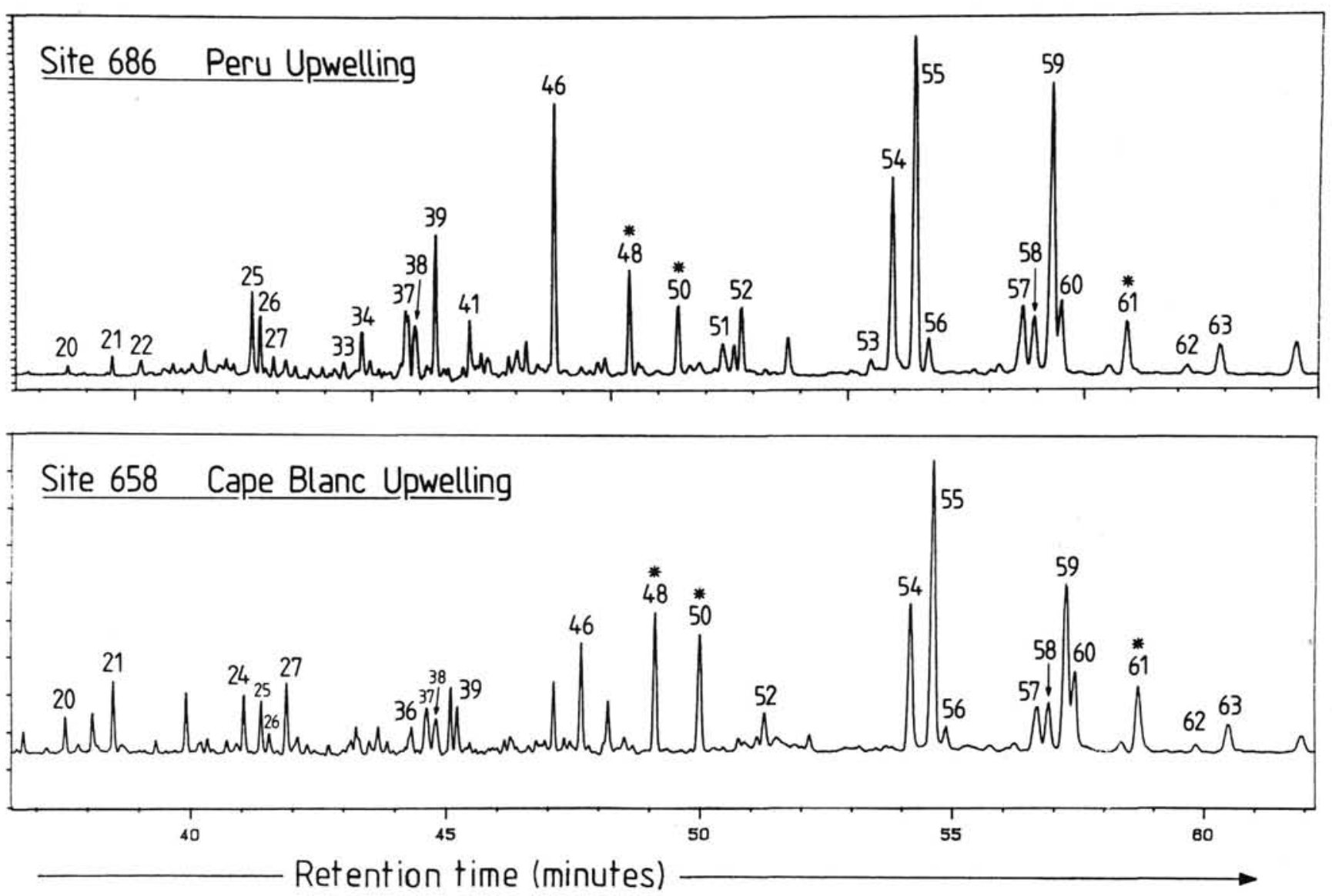

Figure 4. Gas chromatograms illustrating the general similarity between the total lipid extracts of sediments from the Peru upwelling $(112-686 \mathrm{~B}-2 \mathrm{H}-4,40-43 \mathrm{~cm})$ and the Cap Blanc upwelling $(108-658 \mathrm{~A}-1 \mathrm{H}-4,25-27 \mathrm{~cm})$. The compound assignments are listed in Table 1 .

do not agree with the observed biomass composition, particularly in the Peru region. Surprisingly, while alkenones dominate the lipid fraction of the sediments, their presumed source organisms (Prymnesiophyte algae) form only a minor, variable constituent of the biomass. Furthermore, the prominence of diatoms in the water column apparently is not recorded in the lipid signatures of the sediments; 24 -methylsterols (thought to be markers of diatom influx) are only minor constituents of the diatomaceous oozes, (even in surface sediments; Volkman et al., 1987). Apparently, the lipid signature was modified, presumably during transit of the organic debris through the water column. Compounds that resist modification within the marine food web (e.g., alkenones and dinosterol; Volkman et al., $1980 \mathrm{c}$; Harvey et al., 1987) may have been concentrated in the sedimentary record at the expense of more labile compounds, giving a biased record of the biomass composition in the overlying water column.

\section{CONCLUSIONS}

The solvent-soluble organic matter from sediments beneath the Peru upwelling area is dominated by marine-derived lipids (sterols, alkenones, and alkanediols) that are produced in a zone of high surface productivity in the euphotic zone. Terrestrially derived organic matter (long-chain n-alkanes and $\mathrm{n}$-alkanols) is a minor component, at least in this region.

Overall lipid distributions in the Peru upwelling sediments are remarkably similar to those from the Cap Blanc upwelling off northwest Africa. However, terrestrial higher plant mate- rial forms a greater relative proportion of the sedimentary lipids in the latter region.

While it is possible to infer the biological sources of most lipids present in Peru margin sediments, the relative abundances of these sedimentary lipids do not agree with the observed biomass composition in the region. In particular, diatom lipids are apparently minor components of the extractable sedimentary organic matter, while Prymnesiophyte algae (a minor constituent of the biomass) provide the major lipid components.

\section{ACKNOWLEDGMENTS}

We are grateful to the Natural Environment Research Council for GC-MS facilities (GR3/2951 and GR3/3758) and for grants supporting research about molecular stratigraphy (GR3/5957 and GST/02/247). We also thank L. Dyas and A.P. Gowar for GC-MS support, and Y. Hall for typing the manuscript.

\section{REFERENCES}

Boon, J. J., Rijpstra, W.I.C., de Lange, F., de Leeuw, J. W., Yoshioka, M., and Shimizu, Y., 1979. Black sea sterol-a molecular fossil for dinoflagellate blooms. Nature, 277:125-127.

Brassell, S. C., 1984. Aliphatic hydrocarbons of a Cretaceous black shale and its adjacent green claystone from the southern Angola Basin, Deep Sea Drilling Project, Leg 75. In Hay, W. W., Sibuet, J. C., et al., Init. Repts. DSDP, 75: Washington (U.S. Govt. Printing Office), 1019-1030.

Brassell, S. C., and Eglinton, G., 1983. The potential of organic geochemical compounds as sedimentary indicators of upwelling. 
In Suess, E., and Thiede, J. (Eds.), Coastal Upwelling-Its Sediment Record. Part A. Responses of the Sedimentary Regime to Present Coastal Upwelling: New York (Plenum Press), NATO Conf. Ser. IV, 1O(a):545-571.

Brassell, S. C., Wardroper, A.M.K., Thomson, I. D., Maxwell, J. R., and Eglinton, G., 1981. Specific acyclic isoprenoids as biological markers of methanogenic bacteria in marine sediments. Nature, 290:693-696.

Brassell, S. C., Eglinton, G., Marlowe, I. T., Pflaumann, U., and Sarnthein, M., 1986a. Molecular stratigraphy: a new tool for climatic assessment. Nature, 320:129-133.

Brassell, S. C., Brereton, R. G., Eglinton, G., Grimalt, J., Liebezeit, G., Marlowe, I. T., Pflaumann, U., and Sarnthein, M., 1986b. Palaeoclimatic signals recognized by chemometric treatment of molecular stratigraphic data. In Leythaeuser, D., and Rullkötter, J. (Eds.), Advances in Organic Geochemistry. Org. Geochem., 10:649-660.

Cooper, W. T., Heiman, A. S., and Yates, R. R., 1986. Spectroscopic and chromatographic studies of organic carbon in Recent marine sediments from the Peruvian Upwelling Zone. In Leythaeuser, D., and Rullkötter, J. (Eds.), Advances in Organic Geochemistry 1985. Org. Geochem., 10:725-732.

Cranwell, P. A., and Volkman, J. K., 1981. Alkyl and steryl esters in a recent lacustrine sediment. Chem. Geol., 32:29-43.

Demaison, G. J., and Moore, G. T., 1980. Anoxic environments and oil source bed genesis. Org. Geochem., 2:9-31.

Didyk, B. M., Simoneit, B.R.T., Brassell, S. C., and Eglinton, G., 1978. Organic geochemical indicators of palaeoenvironmental conditions of sedimentation. Nature, 272:216-222.

Donegan, D., and Schrader, H., 1981. Modern analogues of the Miocene diatomaceous Monterey Shale of California: evidence from sedimentologic and micropalaeontologic study. In Garrison, R. E., and Douglas, R. G. (Eds.) The Monterey Formation and Related Siliceous Rocks of California. SEPM Pacific Sect. Symp., 149-157.

Dugdale, R. C., Goering, J. J., Barber, R. T., Smith, R. L., and Packard, T. T., 1977. Denitrification and hydrogen sulfide in the Peru upwelling region during 1976. Deep Sea Res., 24:601-608.

Eglinton, G., and Calvin, M., 1967. Chemical fossils. Sci. Am., 216:32-43.

Eglinton, G., and Hamilton, R. J., 1967. The distribution of alkanes. In Swain, T. (Ed.), Chemical Plant Taxonomy: New York (Academic Press), 187-208.

Eglinton, G., Hamilton, R. J., Raphael, R. A., and Gonzalez, A. G., 1962. Hydrocarbon constituents of the wax coatings of plant leaves: a taxonomic survey. Nature, 193:739-742.

Eglinton, G., Brassell, S. C., Howell, V., and Maxwell, J. R., 1983. The role of organic geochemistry in the Deep Sea Drilling Project (DSDP/IPOD). In Bjorøy, M., et al. (Eds.), Advances in Organic Geochemistry 1981: Chichester (Wiley), 391-400.

Farrington, J. W., Davis, A. C., Sulanowski, J., McCaffrey, M. A., McCarthy, M., Clifford, C. H., Dickinson, P., and Volkman, J. K., 1988. Biogeochemistry of lipids in surface sediments of the Peru Upwelling Area at $15^{\circ} \mathrm{S}$. In Matavelli, L., and Novelli, L. (Eds.), Advances in Organic Geochemistry. Org. Geochem., 13:607-617.

Gagosian, R. B., Loder, T., Nigrelli, G., Mlodzinska, Z., Love, J., and Kogelschatz, J., 1980. Hydrographic and nutrient data from Knorr cruise 73, Leg 2-February to March 1978 -off the coast of Peru. Woods Hole Oceanographic Inst. Tech. Rept., 80-1.

Gagosian, R. B., Nigrelli, G. E., and Volkman, J. K., 1983a. Vertical transport and transformation of biogenic organic compounds from a sediment trap experiment off the coast of Peru. In Suess, E., and Thiede, J. (Eds.), Coastal Upwelling-Its Sediment Record. Part A: Responses of the Sedimentary Regime to Present Coastal Upwelling: New York (Plenum Press), NATO Conf. Ser. IV, 1O(a):241-272.

Gagosian, R. B., Volkman, J. K., and Nigrelli, G. E., 1983b. The use of sediment traps to determine sterol sources in coastal sediments off Peru. In Bjorøy, M., et al. (Eds.), Advances in Organic Geochemistry 1981: Chichester (Wiley), 369-379.

Gaskell, S. J., and Eglinton, G., 1975. Rapid hydrogenation of sterols in a contemporary lacustrine sediment. Nature, 254:209-211.
Han, J., and Calvin, M., 1969. Hydrocarbon distribution of algae and bacteria and microbiological activity in sediments. Proc. Nat. Acad. Sci., 64:436.

Harvey, H. R., Eglinton, G., O'Hara, S.C.M., and Corner, E.D.S., 1987. Biotransformation and assimilation of dietary lipids by Calanus feeding on a dinoflagellate. Geochim. Cosmochim. Acta, 51:3031-3040.

ten Haven, H. L., de Leeuw, J. W., and Schenck, P. A., 1985. Organic geochemical studies of a Messinian evaporitic basin, northern Apennines (Italy), I-hydrocarbon biological markers for a hypersaline environment. Geochim. Cosmochim. Acta, 49:21812191.

ten Haven, H. L., Baas, M., de Leeuw, J. W., Maassen, J. M., and Schenck, P. A., 1987. Organic geochemical characteristics of sediments from the anoxic brine-filled Tyro Basin (eastern Mediterranean). Org. Geochem., 11:605-611.

Henrichs, S. M., and Farrington, J. W., 1984. Peru upwelling region sediments near $15^{\circ} \mathrm{S}$. 1. Remineralization and accumulation of organic matter. Limnol. Oceanogr., 29:1-19.

Henrichs, S. M., Farrington, J. W., and Lee, C., 1984. Peru upwelling region sediments near $15^{\circ} \mathrm{S}$. 2. Dissolved free and total hydrolyzable amino acids. Limnol. Oceanogr., 29:20-34.

Kolattukudy, P. E., 1976. Chemistry and Biochemistry of Natural Waxes: Amsterdam (Elsevier).

de Leeuw, J. W., Rijpstra, W.I.C., and Schenck, P. A., 1981. The occurrence and identification of $\mathrm{C}_{30}, \mathrm{C}_{31}$, and $\mathrm{C}_{32}$ alkan-1,15-diols and alkan-15-one-1-ols in Unit I and Unit II Black Sea sediments. Geochim. Cosmochim. Acta, 45:2281-2285.

de Leeuw, J. W., Rijpstra, W.I.C., Schenck, P. A., and Volkman, J. K., 1983. Free, esterified, and residual bound sterols in Black Sea Unit I sediments. Geochim. Cosmochim. Acta, 47:455-465.

Mackenzie, A. S., Brassell, S. C., Eglinton, G., and Maxwell, J. R., 1982. Chemical fossils-the geological fate of steroids. Science, 217:491-504.

Marlowe, I. T., 1984. Lipids as palaeoclimatic indicators [Ph.D. dissert.]. Univ. of Bristol, United Kingdom.

Marlowe, I. T., Green, J. C., Neal, A. C., Brassell, S. C., Eglinton, G., and Course, P. A., 1984a. Long-chain (n-C37-C39) alkenones in the Prymnesiophyceae. Distribution of alkenones and other lipids and their taxonomic significance. Br. Phycol.J., 19:203-216.

Marlowe, I. T., Brassell, S. C., Eglinton, G., and Green, J. C., 1984b. Long-chain unsaturated ketones and esters in living algae and marine sediments. In Schenck, P. A., de Leeuw, J. W., and Lijmbach, G.W.M. (Eds.) Advances in Organic Geochemistry 1983. Org. Geochem., 6:135-141.

Mello, M. R., Gaglianone, P. C., Brassell, S. C., and Maxwell, J. R., 1988. Geochemical and biological marker assessment of depositional environments using Brazilian offshore oils. Mar. Pet. Geol., 5:205-223.

Meyers, P. A., Trull, T. W., and Kawka, O. E., 1984. Organic geochemical comparison of Cretaceous green and black claystones from Hole 530A in the Angola Basin. In Hay, W. W., Sibuet, J. C., et al., Init. Repts. DSDP, 75: Washington (U.S. Govt. Printing Office), 1009-1018.

Morris, R. J., and Brassell, S. C., 1988. Long-chain alkanediols: biological markers for cyanobacterial contributions to sediments. Lipids, 23:256-258.

Nichols, P. D., and Johns, R. B., 1988. The lipid chemistry of sediments from the St. Lawrence estuary. Acyclic unsaturated long-chain ketones, diols, and ketone alcohols. Org. Geochem., 9:25-30.

Nishimura, M., and Koyama, T., 1977. The occurrence of stanols in various living organisms and the behavior of sterols in contemporary sediments. Geochim. Cosmochim. Acta, 41:379-385.

Ourisson, G., Albrecht, P., and Rohmer, M., 1979. The hopanoids. Palaeochemistry and biochemistry of a group of natural products. Pure Appl. Chem., 51:709-729.

Philp, R. P., 1985. Biological markers in fossil fuel production. Mass. Spec. Rev., 4:1-54.

Poutanen, E. L., and Morris., R. J., 1983. The occurrence of high molecular weight humic compounds in the organic-rich sediments of the Peru continental shelf. Oceanol. Acta, 6:21-28. 
Poynter, J. G., Farrimond, P., Brassell, S. C., and Eglinton, G., in press. A molecular stratigraphic study of sediments from Holes 658A and 660A, ODP Leg 108. In Ruddiman, W., Sarnthein, M., et al., Proc. ODP. Sci. Results, 108: College Station, TX (Ocean Drilling Program).

Prahl, F. G., and Wakeham, S. G., 1987. Calibration of unsaturation patterns in long-chain ketone compositions for paleotemperature assessment. Nature, 320:367-369.

Rechka, J. A., and Maxwell, J. R., 1988. Unusual long-chain ketones of algal origin. Tet. Lett., 21:2599-2600.

Reimers, C. E., and Suess, E., 1983. Late Quaternary fluctuations in the cycling of organic matter off Central Peru: A proto-kerogen record. In Suess, E., and Thiede, J. (Eds.), Coastal UpwellingIts Sediment Record. Part A: Responses of the Sedimentary Regime to Present Coastal Upwelling: New York (Plenum Press), NATO Conf. Ser. IV, 10(a):497-525.

Repeta, D. J., and Gagosian, R. B., 1983. Carotenoid transformation products in the upwelled waters off the Peruvian coast: suspended particulate matter, sediment trap material, and zooplankton fecal pellet analyses. In Bjorøy, M., et al. (Eds.), Advances in Organic Geochemistry 1981: Chichester (Wiley), 380-388.

1987. Carotenoid diagenesis in recent marine sediments-1. The Peru continental shelf $\left(15^{\circ} \mathrm{S}, 75^{\circ} \mathrm{W}\right)$. Geochim. Cosmochim. Acta, 51:1001-1009.

Risatti, J. B., Rowland, S. J., Yon, D. A., and Maxwell, J. R., 1984. Stereochemical studies of acyclic isoprenoids-XII. Lipids of methanogenic bacteria and possible contributions to sediments. In Schenck, P. A., de Leeuw, J. W., and Lijmbach, G.W.M. (Eds.), Advances in Organic Geochemistry 1983. Org. Geochem., 6:93104.

Rosenberg, R., Arntz, W. E., de Flores, E. C., Flores, L. A., Carbajal, G., Finger, I., and Tarazone, J., 1983. Benthos biomass and oxygen deficiency in the upwelling system off Peru. J. Mar. Res., 41:263-279.

Rowe, G. T., and Howarth, R., 1985. Early diagenesis of organic matter in sediments off the coast of Peru. Deep Sea Res., 32:43-55.

Ryther, J. H., Menzel, D. W., Hulbert, E. M., Lorenzen, C. J., and Corwin, N., 1971. The production and ultilization of organic matter in the Peru coastal current. Inv. Pesq., 35:43-59.

Schneider, J. K., Gagosian, R. B., Cochran, J. K., and Trull, T. W., 1983. Particle size distribution of $\mathrm{n}$-alkanes and ${ }^{210} \mathrm{~Pb}$ in aerosols off the coast of Peru. Nature, 304:429-432.

Smith, D. J., 1984. Biogeochemistry of lipids in recent organic-rich sediments [Ph.D. dissert.]. Univ. of Bristol, United Kingdom.

Smith, D. J., Eglinton, G., and Morris, R. J., 1983a. The lipid chemistry of an interfacial sediment from the Peru Continental Shelf: fatty acids, alcohols, aliphatic ketones, and hydrocarbons. Geochim. Cosmochim. Acta, 47:2225-2232.

Smith, D. J., Eglinton, G., Morris, R. J., and Poutanen, E. L., 1983b. Aspects of the steroid geochemistry of an interfacial sediment from the Peruvian upwelling. Oceanol. Acta, 6:211-219.

Smith, R. L., 1983. Circulation patterns in upwelling regimes. In Suess, E., and Thiede, J. (Eds.), Coastal Upwelling-Its Sediment
Record. Part A: Responses of the Sedimentary Regime to Present Coastal Upwelling: New York (Plenum Press), NATO Conf. Ser. IV, 10(a):13-35.

Suess, E., Kulm, L. D., and Killingley, J. S., 1987. Coastal upwelling and a history of organic-rich mudstone deposition off Peru. In Brooks, J., and Fleet, A. J. (Eds.), Marine Petroleum Source Rocks. Geol. Soc. Am. Spec. Publ., 26:181-197.

Volkman, J. K., 1986. A review of sterol markers for marine and terrigenous organic matter. Org. Geochem, 9:83-99.

Volkman, J. K., Eglinton, G., Corner, E.D.S., and Sargent, J. R., 1980a. Novel unsaturated straight-chain $C_{3}-C_{39}$ methyl and ethyl ketones in marine sediments and a coccolithophore Emiliania huxleyi. In Douglas, A. G., and Maxwell, J. R. (Eds.), Advances in Organic Geochemistry 1979: Oxford (Pergamon Press), 219227.

Volkman, J. K., Eglinton, G., Corner, E.D.S., and Forsberg, T.E.V., $1980 \mathrm{~b}$. Long-chain alkenes and alkenones in the marine coccolithophorid Emiliania huxleyi. Photochem., 19:2619-2622.

Volkman, J. K., Corner, E.D.S., and Eglinton, G., 1980c. Transformations of biolipids in the marine food web and in underlying bottom sediments. In Colloques Int. du CNRS No. 293-Biogèochimie de la matriére organique a l'interface eau-sediment marin: Paris (Editions CNRS) 185-197.

Volkman, J. K., Gillan, F. T., Johns, R. B., and Eglinton, G., 1981. Sources of neutral lipids in a temperate intertidal sediment. Geochim. Cosmochim Acta, 45:1817-1828.

Volkman, J. K., Farrington, J. W., Gagosian, R. B., and Wakeham, S. G., 1983. Lipid composition of coastal marine sediments from the Peru upwelling region. In Bjor $\varnothing y$, M., et al. (Eds.), Advances in Organic Geochemistry 1981: Chichester (Wiley), 228-240.

Volkman, J. K., Farrington, J. W., and Gagosian, R. B., 1987. Marine and terrigenous lipids in coastal sediments form the Peru upwelling region at $15^{\circ} \mathrm{S}$ : sterols and triterpene alcohols. Org. Geochem., 11:463-477.

Wakeham, S. G., Farrington, J. W., and Volkman, J. K., 1983. Fatty acids, wax esters, triacylglycerols, and alkyldiacylglycerols associated with particles collected in sediment traps in the Peru Upwelling. In Bjorøy, M., et al. (Eds.), Advances in Organic Geochemistry 1981: Chichester (Wiley), 185-197.

Wakeham, S. G., Farrington, J. W., and Gagosian, R. B., 1984. Variability in lipid flux and composition of particulate matter in the Peru upwelling region. Org. Geochem., 6:203-215.

Williams, L. A., 1984. Subtidal stromatolites in Monterey Formation and other organic-rich rocks as suggested source contributors to petroleum formation. AAPG Bull., 68:1879-1893.

Zuta, S., Rivera, T., and Bustamante, A., 1978. Hydrologic aspects of the main upwelling areas off Peru. In Boje, R., and Tomczak, M. (Eds.), Upwelling Ecosystems: Berlin-Heidelberg-New York (Springer-Verlag), 235-257.

Date of initial receipt: 18 October 1988

Date manuscript accepted: 1 June 1989

Ms 112B-149 